FILOLOGIJA 75, Zagreb 2020.

UDK 81'282.2'344(497.529Vrbanci)

DOI https://dx.doi.org/10.21857/yrvgqtegr9

Izvorni znanstveni članak

Rukopis primljen 28. IX. 2020.

Prihvaćen za tisak 8. II. 2021.

Marina Marinković

Filozofski fakultet Sveučilišta u Rijeci

Odsjek za kroatistiku

Sveučilišna avenija 4, HR-51000 Rijeka

m.marinkovic@uniri.hr

\title{
FONOLOŠKE ZNAČAJKE MJESNOGA GOVORA VRBANACA: PRILOG PROUČAVANJU DRAGANIĆKE KAJKAVŠTINE
}

U radu ${ }^{1}$ se na temelju građe prikupljene vlastitim terenskim istraživanjima opisuje fonološka razina mjesnoga govora Vrbanaca. Selo Vrbanci dio su Općine Draganić smještene u neposrednoj blizini grada Karlovca. U dosadašnjim dijalektološkim radovima draganićki govori nisu opsežnije opisivani, premda se nalaze na samom razmeđu dvaju dijalekata kajkavskoga narječja: plješivičko-ozaljskoga i vukomeričko-pokupskoga (te dviju Ivšićevih grupa, prve i treće). Analizom dijalektnoga materijala utvrđeno je da se fonologija ovoga idioma unekoliko razlikuje od susjednih govora ozaljskoga tipa, no i da postoji niz fonoloških značajki koje ga uz te govore vežu: monoftonški voka-

1 Terensko istraživanje draganićkoga kraja provedeno je u okviru znanstvenoistraživačkoga projekta Popunjavanje bjelina na suvremenoj i povijesnoj kajkavskoj jezičnoj karti čija dijalektološka istraživanja financijski podupiru Karlovačka županija i Zaklada Hrvatske akademije znanosti i umjetnosti.

Kajkavološka istraživanja u Akademijinu Zavodu za lingvistička istraživanja provođena su dugi niz godina u okviru projekta Istraživanje hrvatskih dijalekata i povijesti hrvatskoga jezika. Uz mnogobrojne znanstvene radove, jedan je od istaknutih rezultata zavodskih znanstvenih napora u domeni istraživanja kajkavštine i opsežan Opis $i$ rječnik đurđevečkoga govora (Maresić-Miholek 2011). Kada su u novije vrijeme, u duhu sveopćega nastojanja za očuvanjem nematerijalne baštine, lokalne zajednice pokazale interes za sudjelovanjem (prvenstveno financijskom potporom) $\mathrm{u}$ takovim istraživanjima, ukazala se potreba za formiranjem kajkavološke grupe koja je u Zavodu, na čelu s akademikom Augustom Kovačecom, započela s radom na proučavanju dosad zanemarene kajkavske sastavnice hrvatske tronarječnosti, i suvremene i povijesne. U sinergiji s vanjskim suradnicima, od 2019. godine započela su tako intenzivna terenska istraživanja kajkavskih mjesnih govora te kajkavskoga književnoga jezika unutar povijesne sekcije projekta. 
Marina Marinković: Fonološke značajke mjesnoga govora Vrbanaca: prilog proučavanju...

FILOLOGIJA 75(2020), 99-118

lizam, prisutnost frikativa ś i ź te afrikata $̌$ i ć u konsonantskome inventaru, očuvanje poluglasa u slogu s kratkim akcentom i dr. S druge strane, jat i u dugim i u kratkim slogovima daje zatvoreno ẹ/e (za razliku od obližnjih zapadnijih govora s ikavsko-ekavskom zamjenom jata), a distribucija neoakuta bliska je distribuciji u govorima prodindolskoga tipa, pri čemu neoakut dolazi i na starome i na novome mjestu. Posebno su u ovome govoru zamjetne fonemske zamjene $(o \rightarrow$ $u, o \rightarrow e, e \rightarrow i ; o \rightarrow a$ rijetko), čime se on uvelike identificira s ostalim govorima na najistočnijemu kraku plješivičkoprigorske kajkavštine. $\mathrm{S}$ obzirom na navedene sumarne značajke, u radu se mjesni govor $\mathrm{Vr}-$ banaca preciznije pozicionira na karti jugozapadnoga dijela kajkavskoga narječja, na liniji Ozalj - Tuškani - Domagović.

\section{Uvod}

Ojkonim Draganić u brojnim se i raznovrsnim izvorima uglavnom iz različitih povijesno-tradicionalnih razloga posve izjednačuje s množinskim oblikom Draganići. Međutim, pri interpretaciji broja naselja o kojima se govori i pri njihovu imenovanju nerijetko se donose zbunjujući pa i oprečni podaci, s obzirom na to da morfološka dubleta Draganić || Draganići nije samo lingvističke prirode, već da njenu pozadinu valja tražiti kako u povijesnim vrelima, tako i u stvarnome stanju na terenu. Pojašnjenjem te onomastičke zavrzlame moći ćemo i precizirati predmet našega istraživanja.

Općina Draganić smještena je u Karlovačkoj županiji, na njenom rubnome, sjeveroistočnome dijelu. Službeni podaci ${ }^{2}$ govore da se unutar te administrativne jedinice nalazi više naselja, među kojima pronalazimo i naselje Draganići. Međutim, u svakodnevnoj komunikaciji mještana širega područja oba imena ulaze $u$ sinegdoške odnose. ${ }^{3} \mathrm{U}$ povijesnim vrelima zbir navedenih sela objedinjuje se pak pod krovnim imenom Draganići, ${ }^{4}$ a

2 »Naseljeno mjesto Draganić oduvijek je činilo zajedništvo 17 sela (zaselaka, kako se to reklo): Draganići (istaknula M. M.), Barkovići, Jazvaci, Vrbanci, Budrovci, Bencetići, Goljak, Mrzljaki, Vrh, Križančići, Lazina, Franjetići, Lug i Darići koji su i sada te Čeglji, Guci i Vukšin Šipak, koji su izvan ustroja općine Draganić, ali pripadaju Župi draganićkoj« (http://www.draganic.hr/sadrzaj.php?gs=1m, pristupljeno 1. rujna 2020.).

3 U terenskim istraživanjima karlovačkoga područja zabilježila sam tako sljedeće izjave: Prẹšli su f Dräganiçe (iz konteksta se saznaje da se subjekt zapravo uputio u zaselak Lug; izjava je snimljena u selu Šišljavić) ili Väj’k po Dräganiću ôda (ovdje je Draganić = selo Lazina; izjava je snimljena u selu Brežani).

4 »Prava je blagodat za Draganiće (istaknula M. M.), da kroz obćinu od sjevera iz žumberačkih gorah pak prema jugoiztoku teče Kupčina, najveći pritok Kupe na lie- 
novija leksikografska djela također nude različita tumačenja. ${ }^{5}$

U istraživanju govorâ draganićkoga kraja stariji radovi (Ivić 1968; Finka-Šojat 1973) ne preciziraju punktove svoga užeg interesa i čini se da ih motre kao jednu cjelinu. No, dodamo li dijalektološkim načelima klasifikacije $^{6}$ i činjenicu kako je riječ o višestruko rubnome području na kojem su znatne razlike već na malom teritoriju sasvim očekivane, u ovome radu donosit će se zaključci samo na temelju građe prikupljene vlastitim terenskim istraživanjem u zaselku Vrbanci.

Građa je za ovaj rad prikupljana u nekoliko navrata 2019. godine. U prvoj fazi istraživanja snimljena je obimna količina dijalektnoga materijala u formi spontana govora čijom je transkripcijom dobivena glavnina podataka potrebnih za izradu rudimentarne fonološke skice. U narednim fazama rada ti su podaci dopunjavani i provjeravani ciljanim ispitivanjima. Istraživanje je provedeno s dvama ispitanicima starije životne dobi, što implicira da je u ovome radu prikazan stariji sloj analiziranoga govora. Jezične mijene zahvatile su, dakako, i primarno (ponajprije akcentološki) konzervativne govore draganićkoga područja. No, radi formiranja što jasnije slike o poveznicama i razlučnicama među genetski srodnim sustavima u široj okolici (s jedne strane ozaljskim govorima ikavsko-ekavskoga tipa, a s druge strane prigorskim govorima kakve je još koncem 19. st. opisao Vatroslav Rožić), cilj je ove analize prikaz starijega stanja fonološke razine govora Vrbanaca. Istovremeno to ne isključuje nasušnu potrebu da se i o intenzivnim tendencijama (sada već i uznapredovalim procesima) općekajkavske dijalekatske nivelacije, kao i nivelacijama regionalnoga tipa, $u$ skorijoj budućnosti istražuje i piše.

voj obali, (...). Poveljenoj obćini Draganićkoi pripojena su od zemana sela Petaki, Lazina, Borkovići, Vrbanci, Budrovci, Mržljaki, Cegli, Izimje, Trg, Franjetići, Darići, Gudci, Jazvaci, Križanci (...). G. 1869. bilo je polag popisa u Draganićih 4500 dušah (Lopašić 1883:2). O nekadašnjoj draganićkoj općini usp. i Laszowski 1899.

5 Djelo Imena hrvatskih naselja (Grčević 2008) pri tome vjerno odražava suvremenu administrativnu sliku (naselje Draganići u Općini Draganić), dok Hrvatski mjesni rječnik (2016) donosi samo jedninski oblik imena za obje jedinice. Summa summarum, u iznesenu ojkonimsku petlju lakše ćemo proniknuti zahvaljujući spoznajama o razvitku hrvatskih ojkonima, činjenici da su se stari patronimni ojkonimi s vremenom singularizirali, »identificirajući tako jedinačnost lokaliteta, a ne više mnoštvo, ljudsku zajednicu (...)« (Šimunović 2009:222). Draganići su, prema tome, starije ime, relikt nekadašnjega suživota zajedništvâ više rodova (Barkovići, Jazvaci, Mržljaki...), a ime Općine Draganić rezultat imenovanja cjelokupnoga područja prema metonimijskome principu i prema važećim uzusima u razvitku ojkonima.

6 O jednome mjesnome govoru kao temelju dijalektološkoga istraživanja govorio je već Trubeckoj, a tu su premisu preuzeli i drugi, među kojima i hrvatski lingvisti (Brozović 1970). O sustavima u dijalektologiji usp. Lončarić 1977. 
Marina Marinković: Fonološke značajke mjesnoga govora Vrbanaca: prilog proučavanju... FILOLOGIJA 75(2020), 99-118

Osim prikaza fonološke slike mjesnoga govora Vrbanaca, nakon detaljnijega uvida u prikupljenu građu, kao i nakon upoznavanja sa širim dijalektološkim kontekstom u koji je analizirani govor uronjen, u svjetlu njegove pozicije na sjecištu brojnih izoglosâ iskristalizirao se još jedan cilj ovoga rada: smjestiti analizirani govor u raster južnih i jugozapadnih govora prigorske kajkavštine te odrediti međusobne sličnosti i razlike.

\section{Starija i novija istraživanja ozaljsko-draganićkoga areala}

Razmotrivši sve spoznaje dosadašnjih dijalektoloških istraživanja, draganićka skupina govora, pa tako i govor Vrbanaca, priključuje se kajkavskomu plješivičko-ozaljskomu dijalektu. ${ }^{7}$ Karakterizira ga s jedne strane niz značajki koje starija literatura pridružuje tzv. središnjim govorima te, $s$ druge strane, zamjetan broj značajki koje su tretirane kao rubne: izostanak jednačenja odrazâ poluglasa i jata, prisutnost frikativa ś, ź, vokala a, afrikata č i ć i dr. Ne ulazeći u opravdanost takovih imenovanja ('središnje' prema 'rubnom'), prije same analize prikupljena dijalektnoga materijala kronološki ćemo predočiti razvoj dijalektološke misli o jezičnome identitetu tog segmenta hrvatske dijalektološke slike.

U većini dijalektoloških kajkavoloških istraživanja, pa tako i u ovome, pri traženju najstarijih podataka o pojedinom analiziranom idiomu donja se granica nerijetko zaustavlja na rezultatima Ivšićeve dijalektološke ekspedicije. Pri tome je, naravno, u njegovu radu poimence spomenut tek mali broj punktova, no ono što inicijalno pomaže u pozicioniranju kojega govora u širi dijalektološki kontekst njegova je Karta hrvatskih kajkavskih akcenatskih tipova. I bez aproksimativna gledanja, razvidno je iz spomenute karte da prema akcenatskomu kriteriju ozemlje Draganića pripada konzervativnoj prvoj skupini, kao i to da ga vrlo malo dijeli od izoglose koja taj teritorij dijeli od istočnijih govora treće skupine s revolucionarnom distribucijom naglasaka. Upravo je uz područje Draganića na spomenutoj karti ucrtana i shema akcenatskoga tipa $\mathrm{I}_{6}$ iz koje iščitavamo da je već u vrijeme Ivšićeva istraživanja u draganićkoj skupini govora provede-

7 Nazivlje je u slučaju ove apstraktne dijalektološke jedinice unazad nekoliko desetljeća unekoliko mijenjano. Skupina govora na području od Plešivice i svetojanskoga kraja na sjeveru i sjeveroistoku do Karlovca i Ozlja na jugu i jugozapadu dugo je u literaturi bila objedinjena pod krovnim terminom prigorskoga dijalekta (Brozović 1988:92-93). Zatim je, s dorađenijom i preciznijom podjelom, tomu sustavu pridruženo određenje 'plješivičkoprigorski' (Lončarić 1996). Uzimajući u obzir neprikosnoveni klasifikacijski kriterij odraza jata koji je u ikavsko-ekavskome govoru Ozlja drugačiji od odrazâ u ostatku dijalekta, u novije se vrijeme u naziv uključuje sastavnica 'ozaljski'. 
na dezoksitoneza te da je neoakut na polaznome mjestu zamijenjen dugim silaznim naglaskom, a očuvan onaj retrakcijskoga postanja. Pogledamo li u smjeru istočnoga dijela plješivičko-ozaljskoga dijalekta i usporedimo li shemu obližnjega Domagovića (tip $\mathrm{I}_{5}$ ), vidimo da je već u tome punktu neoakut na starome mjestu očuvan, što su posvjedočila i novija istraživanja (Galić-Lisac 2017:139). S druge pak, zapadne strane, ozaljski ga govori u tome položaju nemaju, kao ni Ozlju geografski blizak govor Tuškanâ. Autor opisa tuškanske fonologije u draganićkome je selu Lug uočio fakulta-

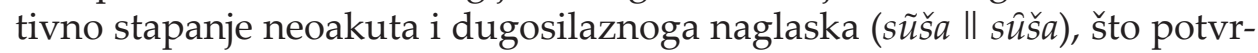
đuje da je upravo draganićki kraj prostor prijelaznih akcenatskih tipova unutar cjeline prigorske kajkavštine. Nove spoznaje o sudbini neoakuta u govoru Vrbanaca mogle bi dodatno izoštriti izoglose njegova očuvanja na starome mjestu. Kada je riječ o mjesnome govoru Draganića, ${ }^{8}$ bitno je spomenuti i da je on svoje mjesto pronašao na još starijima dijalektološkim zemljovidima, kao strateška točka razmeđa dvaju narječja: na Lukjanenkovoj Karti kajkavskog narječja iz 1905. (priložena u Lončarić 1996:14) lijepo se vidi da, u tadašnjem poimanju, upravo precizno kroz Draganić prolazi izoglosa koja dijeli kajkavsko narječje od čakavskoga. Budući da iz toga vremena o karlovačkome arealu imamo spoznaje samo iz opsežna Strohalova opisa govora kotara karlovačkoga u kojem se o samome Draganiću ne navodi mnogo,${ }^{9}$ moguće je da je takvo iscrtavanje motivirano i starom međom dvaju predmigracijskih narječja hrvatskoga jezika. ${ }^{10}$ Koliko je ona vidljiva u današnjim karakteristikama, pokazat će poglavlja koja slijede.

Iz tridesetogodišnjeg razdoblja između Ivšićeva nacrta do konca 60-ih godina prošloga stoljeća nemamo spoznaja o promatranome arealu. Godine 1968., kako je već spomenuto, govoru Draganića pridana je veća pažnja u Ivićevu široku pregledu kajkavskih vokalskih sustava, s osobitim naglaskom na fonološke neutralizacije, a koje se upravo u draganićkom govoru obilato pojavljuju. Iz teksta se jasno iščitava da je Ivić građu crpio iz vlastitih terenskih zabilježaka. Kajkavskoga identiteta draganićkoga govora uz-

8 Bilo o jednome govoru ili o skupini govora.

9 Sâm Draganić Strohal spominje izrijekom na početku rasprave, navodeći da je, gledajući cjelinu tadašnjega karlovačkoga kotara, »kajkavština jača u sjevernom i sjevero-iztočnom dijelu kotara, tako od većih mjesta napose u Erjavcu, Ozlju, Pokuplju, Mahičnom, Draganiću i Šišljaviću« (1901:78). Dalje se u tekstu rijetko vraća na odraze i njihove primjere potvrđene u Draganiću te »jezik kotara karlovačkoga « opisuje kumulativno. Iz uvodnoga poglavlja saznajemo i da je naslovna administrativna jedinica rasprostranjena na veoma velikome prostoru, u dijalektološkome pogledu izuzetno heterogenome, i da se obrađuje čakavsko-kajkavska sastavnica toga idioma. U svemu, Strohalova se analiza uzima u obzir tek kao članak informativne prirode.

10 Položaj predmigracijske kajkavštine i čakavštine usp. u Lončarić (1996:38). 
gredno se dotiču i autori rasprave o karlovačkome govoru: »Već su Draganići mjesto koje se u svakoj dijalekatskoj klasifikaciji mora uključiti u integralno kajkavsko narječje« (Finka-Šojat 1973:115). Međutim, ni u jednom od navedenih dvaju izvora nigdje se izrijekom ne ističe referiraju li se ponuđeni primjeri na jedan ili više susjednih govora (usp. 1. Uvod i bilj. 2). Nakon Ivićevih istraživanja te usputnih crtica iz radova kojima je $u$ fokusu neki od obližnjih mjesnih govora (poput Težakova opisa ozaljskoga iz 1981.) nastala je opet lakuna u ciljanu proučavanju draganićke skupine govora. Vraćamo im se tek u novom tisućljeću. Draganić tako postaje predmetom studentskih istraživanja (Šebetić 2015), ali i ozbiljnijih pristupa koji na prostoru draganićke općine luče više mjesnih govora. Najnoviji je u tom pogledu predani rad Matije Mužeka (2020) koji u opsežnoj studiji o govoru obližnjih Tuškana komparabilno donosi potvrde i iz draganićkih sela Lug i Lazina. ${ }^{11}$

Promatrajući razinu dijalekta, područje se ipak ne može smatrati neistraženim, iako su se gotovo stotinu godina neka obilježja toga entiteta mogla upoznati samo iz Rožićeve studije. Obližnji govor Domagovića dobro nam je poznat kao punkt Općeslavenskoga lingvističkoga atlasa ${ }^{12}$ i kao govor s upečatljivim vokalskim zamjenama, a u novije su vrijeme spoznaje o njem produbljene istraživanjem autorskog dvojca Galić-Lisac (2017). Uz Domagović prikazan je i govor sela Petrovine smještenog između Pribića i Jastrebarskog. Na lijevome ogranku prigorske kajkavštine područje Ozlja također je dijalektološki dobro pokriveno, čemu je doprinijelo i spomenuto novije istraživanje Tuškanâ, te prethodno akcentološko istraživanje i Tuškanima susjednoga ikavsko-ekavskoga Mahična ${ }^{13}$ (Kapović 2011:190193). Uzevši u obzir činjenicu da se na geografski malome prostoru na potezu Ozalj - Mahično - Tuškani - Draganić - Domagović nalaze govori koji imaju već različite odraze jata, jasno je da je riječ o vrlo izdiferenciranoj dijalektološkoj slici, kakva je i očekivana na tzv. rubnim područjima dodira dvaju narječja, u ovome slučaju kajkavskih pokupskih govora (pozicioniranih uglavnom na lijevoj obali Kupe) i čakavskih govora kontinentalnoga tipa.

\footnotetext{
11 Lug je od Vrbanaca udaljen oko 5, a Lazina oko $2 \mathrm{~km}$.

12 Samim time prikazan u Fonološkim opisima iz 1981. (Zečević 1981).

13 U dijelu literature i u fonološkoj inačici Mahićno.
} 


\section{Fonološka analiza}

\subsection{Vokali}

\subsubsection{Inventar i realizacija}

U naglašenoj poziciji vokalski inventar govora Vrbanaca broji 7 fonema $\mathrm{u}$ kratkome te 6 fonema u dugome slogu:

$i$

$$
\text { e }
$$$$
\text { e }
$$

$a$ $u$

$o$ $\bar{\imath}$
$\bar{\imath} \quad \bar{u}$
$\bar{e} \quad \bar{\varphi}$
$\bar{e}$

$\bar{a}$

U nenaglašenom slogu vokalski inventar čine $4^{14}$ fonema:

$i$

(e)

(o)

$u$

\section{e}

$a$

U funkciji silabema pojavljuje se i r , u naglašenome kratkom i dugom, te u nenaglašenome slogu: virxńa, virgle pr. r. ž., štr̂̌čki $\mathrm{N}$ mn. 'tvrd, središnji dio pera', $z_{\text {žrt }}$ záprl pr. r. m., držî 3. jd. prez.

Kao i nenaglašeni otvoreni e, i dugi otvoreni vokal $e$-tipa izgovora se zatvorenije nego li kratki naglašeni otvoreni ẹ çiji je izgovor vrlo širok. Jedino je u prikupljenoj građi zamjetno otvaranje dugoga $\bar{e}$ do vokala $\bar{a} \mathrm{u}$ primjeru [tâl'e] 'tele'. Vokalski je sustav monoftonški, no na mjestu dugoga zatvorenoga vokala ẹ, podrijetlom od jata, nerijetko se uočava diftonš-

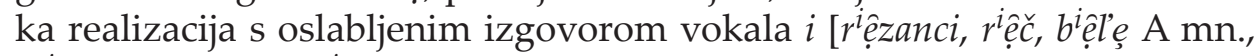
sciệpa 3. jd. prez., riẹttko]. Dugi ā izgovara se vrlo zatvoreno, u slogu s dugosilaznim naglaskom nerijetko s alofonom ọ: [krộf $\mathrm{G}$ mn., na pộšu A jd.].

\subsubsection{Distribucija i razvoj vokalâ}

Vokalizam mjesnoga govora Vrbanaca, kao i vokalizme niza ostalih govora na istočnome dijelu plješivičko-ozaljskoga dijalekta (usp. u Literaturi o govoru Domagovića), karakteriziraju neutralizacije fonoloških opreka koje su u konačnici rezultirale promjenama u distribuciji, a nadasve smanjenjem broja vokala u nenaglašenu slogu, budući da se glavnina fonemskih zamjena odvija upravo u toj poziciji. Razvoj polaznih vokala, odnosno njihovi odrazi na sinkronijskoj razini u uskoj su sprezi s distribucijskim

14 O vokalskim podsustavima ovisnima o prozodijskome i fonemskome kontekstu usp. poglavlje 3.1.2. Nenaglašeni vokali ẹ i o potvrđeni su u primjerima odstupanja od utvrđenih obrazaca fonemskih neutralizacija pa se stoga ovdje smatraju rubnima. 
Marina Marinković: Fonološke značajke mjesnoga govora Vrbanaca: prilog proučavanju... FILOLOGIJA 75(2020), 99-118

ograničenjima, stoga se u takovu tipu govora distribucija vokalâ i njihov razvoj obrađuju zajedno. Izvan sloga s akcentom u analiziranu govoru Vrbanaca tako u načelu ne dolazi vokal e, dok sudbina vokala $o$ ovisi o prozodijskim čimbenicima i fonemskome kontekstu. Za razliku od govorâ na zapadu kajkavskoga teritorija (govori gornjosutlanskoga dijalekta, zapadnoga poddijalekta goranskoga dijalekta i dr.), odrazi su i primarno i sekundarno naglašenih vokala podudarni pa isticanje naglasne kronološke komponente $\mathrm{u}$ opisu ovoga govora nije funkcionalno.

Polazni vokal *e u kratku se naglašenu i nenaglašenu slogu razvio kao e,, u dugome slogu kao ẹ pod dugosilaznim, te kao e pod dugouzlaznim naglaskom: sệlo, mẹdda G jd., zamẹtal pr. r. m. jd., tệlci, ispẹéci, pẹekli pr. r., dẹbbẹle N mn., póstẹla, dọjdẹ; zệle, mẹlla, pẹrrjẹ. Prednji nazal rezultirao je u govoru Vrbanaca također $\mathrm{u}$ dugome slogu zatvorenim é pod silaznim, te otvorenim ę pod uzlaznim naglaskom, dok je u objema kratkim pozicijama, u kratkom naglašenom i nenaglašenom slogu dao ẹ: svẹ̃zal pr. r. m., pệtak, žệja, vodẹ G jd., po rệdu Ljd.; zẹt, dẹsest, narẹdili pr. r. m. mn. Na njihove odraze ne djeluju distribucijska ograničenja. Iznimno je u primjeru jačmẹna G jd. potvrđena zamjena prednjega nazala prema distribucijskim načelima čakavskoga tipa, što se može tumačiti interferencijom s obližnjim zapadnijim čakavskim govorima karlovačkoga zaleđa (usp. Marinković 2017. za punkt Zadobarje). U glagolskim prefiksima pro- i raz- (< ${ }^{*}$ orz-) također dolazi do zamjene vokalâ, no kako je tu riječ o prijevoju vezanome uz morfološku činjenicu, ove alternacije ne promatramo u svjetlu prethodno opisanih neutralizacija koje su uvjetovane fonološkim činiteljima. Promjene pro- > prẹi raz- > ręz- dosljedne su, ${ }^{15}$ a iz građe izdvajamo dio potvrda: prẹminíil, pressẹllilo, prẹ́šal, prẹbudîla, resstalila, resskopàti, resspẹ̦àti, resskãpaj, rẹ̇zdilil. Vokal ẹ nastaje u govoru Vrbanaca i kontrakcijom slogova unutar zamjeničkih oblika: kệ A mn. ž., mệga mûža G jd., svệga G jd. Vokal $i$ u nenaglašenim nastavcima pridjevsko-zamjeničke deklinacije te u nekim gramatičkim morfemima kosih padeža ( $\mathrm{G} \mathrm{jd}$. sûviga, šẹstiga, jẹniga, vệ́iga, lệpimu DL jd., kộnif $\mathrm{G}$ mn.) tumačimo kao zamjenu e $\rightarrow i$, što znači da se u dijelu potvrda u nenaglašenoj poziciji *e razvilo kao e, ali i da je u kosim padežima provedena neutralizacija opreke po palatalnosti, odnosno da su u GDL jd. pridjevske sklonidbe preuzeti nastavci meke promjene. Kao e ponaša se i nenaglašeni $e$ u posuđenici ‘beton': pitọnnu L jd.

Jat je u kratkome i dugome naglašenome slogu dao zatvoreno ẹ/ẹ: dẹda A jd., lẹpssi, nẹdẹla, kulẹno, dẹca, pẹsma, vrẹcces A mn., cvệt, lệpo, navệk, lệt $\mathrm{G}$ mn., narệžem 1. jd. prez., mlệko \|l mlệko. Iznimno je u glagolu tirati i njego-

15 Promjena tipa pro- > pre- značajkom je širega kajkavskoga teritorija (usp. Mitrinović 1990; Maresić 2017). 
vim oblicima (tira 3. jd. prez., tiral pr. r. m.) potvrđen u naglašenoj poziciji ikavski odraz, no tu se može govori o stalnome ikavizmu. Primjeri poput sidî 3. jd. prez., dicệ G jd., tribile pr. r. ž., slipî́, misilo pr. r. s., bižı̂ 3. jd. prez., óbit, sidẹla pr. r. ž., dičkộf $\mathrm{G}$ mn., tiràle pr. r. ž., riźinée 'grančice vinove loze nakon obrezivanja', reflektiraju zatvoreno e na mjestu jata u nenaglašenoj poziciji, neutralizirano s vokalom $i$.

U inicijalnoj poziciji (upẹres, ubrî̌ș, udsẹčçem, utpẹ̦ãaju) te iza gravisnih ${ }^{16}$ glasova vokal $o \mathrm{u}$ nenaglašenome se položaju zamjenjuje vokalom $u$ : kûgluvi $\mathrm{N}$ mn., guvórila, zakupâala, kubiles $\mathrm{N}$ mn., kubîl G mn., bugatẹji komp., kusim 1. jd. prez., nadrubilu pr. r. s., vuditi, pusušilu pr. r. s., kulệna N mn., seḷâkuf G mn., z mlệkum I jd., dvuriśe, kuriti 'korito', Kuzầk'17 ‘Kozak', làfku. Iza ostalih se suglasnika izvan naglašenoga sloga zamjenjuje vokalom $i$ : dinẹsla, dinẹsẹm, dipẹlãju, dipẹ,â, dižĩvila, tripina 'trop, kom', divlẹkli, tirica, 18 tiporica 'držalo', žiti, di 'do, prijedlog', nisile pr. r. ž., pridàti 'prodati', trisif G mn., dimộf 'kući', mệsi, ràni 'pril. rano' sệni, zãati 'zato', násilil pr. r. m., rãstim I jd., kuriti, bridiśę (< ${ }^{*}$ brodiśę 'gaz'). U oba slučaja neutralizacije $(o \rightarrow$ $u ; o \rightarrow i)$ vokalski podsustav u nenaglašenome slogu čine samo 4 fonema $(i$, $e, a, u)$. Uz leksem u značenju 'vino' informanti su u slobodnu govoru rabili dvije fonološke inačice: vini II vine, a osim toga u građi su potvrđeni i primjeri zãstẹr i zẹrnica, kao relikti međufaze $o \rightarrow e$ u slijedu $o \rightarrow e \rightarrow i$, prije nego se vokal o u nenaglašenu položaju u datom fonemskome kontekstu nije izjednačio s odrazom nenaglašenoga jata. Vokal ẹ (na mjestu jata) $\mathrm{u}$ reliktu gramatičkoga morfema duala nije neutraliziran vokalom $i$, najvjerojatnije zbog sprječavanja morfološke homonimije između duala i množine (trî mûžẹ náši mûži): dvâa-trî dãnẹ, trî sándukẹ, trî mûžẹ.

Kratko naglašeno $o\left(<{ }^{*}\right)$ neutralizirano je vokalom e, osim u inicijalnoj poziciji te iza gravisnih konsonanata ${ }^{19}$ nakon kojih se zamjena ne provodi: dẹšla, dẹli ‘dolje', krệp, stẹl, nazẹvve 3. jd. prez., nẹsila pr. r. ž., dẹma, tẹplo óbuta, óbit; na póslu, kósili, lóza 'šuma'. Zamjena kratkoga naglašenoga vokala $o$ vokalom $a$ iza gravisnoga sonanta $m$ u građi je potvrđena samo u primjeru nẹ márẹm. Dugo je polazno *ō rezultiralo zatvorenim ọ̣: kvộčka, komộre, širộki, lộtra, škọle G jd.

16 O gravisnim glasovima usp. Turk 1996:43.

17 Informantica koja je ovjerila ovaj izraz rođena je 1935. pa se dobro sjeća dolaska ruskih vojnika u selo tijekom II. svjetskoga rata.

18 Bot. 'dvozub (korov) Bidens tripartita L.'; na široku prostoru kajkavskoga narječja ova se biljka, u različitim akcenatskim i vokalskim inačicama, imenuje kao torica: u Gorskome kotaru tórica u Osojniku, odnosno torica u Lukovdolu, u karlovačkome Pokuplju zabilježila sam potvrdu torica (Brežani), dok u kajkavskim podravskim govorima dolazi kao pluralia tantum: torîce (Maresić-Miholek 2011:729).

19 Popisu glasova koji u govoru Vrbanaca uzrokuju neutralizaciju vokala $o$ treba pridružiti i alveolar $l$. 
Marina Marinković: Fonološke značajke mjesnoga govora Vrbanaca: prilog proučavanju...

FILOLOGIJA 75(2020), 99-118

Navedene fonološke zamjene u suglasju su s Ivićevim opažanjima koje je o govoru Draganića iznio koncem 60-ih godina prošloga stoljeća: »(...) sudeći po mom materijalu iz Draganića, kratko $o$ je izjednačeno sa kontinuantom $\check{e}$, pa se zatim izjednačilo sa $i$, kao i ě u istom položaju (...) Pojava izostaje u slučajevima gde se vokal $o$ nalazi na početku reči, ili mu prethodi velar, labijal ili $l(\ldots) \ll(1968: 62) .{ }^{20} \mathrm{No}, 50$-ak godina nakon njegova istraživanja očekivano su zabilježena i mnoga odstupanja od utvrđenih formula pa valja posebno naglasiti da se i kod starijih govornika zamjene ne provode dosljedno i da je tijekom razgovora više puta uočeno prebacivanje koda, tako da je u građi ovjeren i niz primjera poput ogńiśes, ponaklê, počináli 'odmorili', košârami I mn., korîta $\mathrm{N}$ mn., dóftorica, vĩno, itd. Ipak, želeći prikazati starije stanje, u ovome radu nenaglašeni vokal $o$ tretiramo kao rubnu, inovativniju pojavu pa je u skladu s time i u prikazu nenaglašena vokalskoga trokuta markiran zagradom (usp. bilj. 14). Donesene iznimke govore i da je zamjena $o \rightarrow u$ mnogo nestabilnija od zamjene $o \rightarrow e$.

Poluglas je sačuvan pod kratkim naglaskom. U nenaglašenom slogu i pod dugim naglaskom izjednačuje se s a/ă: dànas, dànašńi, sàt 'sad', sàda, kàbal, zatàknala pr. r. ž., dàska, dàlęe, bàdań, sànam 1. jd. prez., zàmi 2. jd. imp.; vẹttar, sẹdam, trî dãnẹ, lận, pần. Međutim, potvrđen je na mjestu poluglasa $\mathrm{u}$ kratkome naglašenome slogu i vokal $a$, najučestalije u imenici máša koja se pronalazi i u drugim draganićkim govorima i koja se (uzimajući u obzir pretpostavljen lik *màša) tu interpretira kao posuđenica iz čakavskoga ${ }^{21}$

20 Za obje situacije iznosi i potvrde, od kojih ovdje donosimo samo neke: rèsa (u značenju 'rosa', nap. M. M.), zèrja, nisnìcẹ; ôsta G jd. 'octa', blâgọ, kobïla, koláčẹ. Zanimljivo je da Ivić tada nije detektirao zamjenu $o \rightarrow u$, no kako ne znamo pouzdano u kojem draganićkom selu je provodio istraživanje, ne možemo povlačiti paralele s današnjim govorom Vrbanaca. Međutim, ako pogledamo današnju sliku, vidimo da neutralizacija $o \rightarrow u$ u govoru Vrbanaca nije stabilna te da već i površnim pregledom građe možemo zaključiti da je omjer njena pojavljivanja (kubîl $\mathrm{G}$ mn.) i njena izostanka (korîta) podjednak. Moguće je da je već i u vrijeme Ivićeva istraživanja draganićkoga kraja kolebanje bilo izraženo i da je on $o \rightarrow u$ protumačio fonetski pa ga u tadašnjem duhu strukturalizma smatrao irelevantnim. U govoru Domagovića ona je konzekventna, $u$ Tuškanima varijabilna, kao i u Vrbancima, pa je vjerojatno i Ivić istraživao u zapadnijem dijelu draganićke skupine govora, u smjeru Vrbanaca i Tuškanâ.

21 Tradicijski se u dijalektološkoj literaturi nepreventivna vokalizacija poluglasa u slabom položaju promatrala kao činjenica govorâ čakavskoga narječja, pri čemu joj je pridruživan status alijetetne značajke (Moguš 1977:20-21). Promotrimo li razvoj u I jd. osobne zamjenice manom $\|$ manon $\|$ manum $(<*$ mənojo) u čakavskome naspram štokavskoga mnom(e) uistinu se čini da je tomu tako. No, kontinuiranim istraživanjem kajkavskih govora premisa o nepreventivnoj vokalizaciji kao ekskluzivnoj čakavskoj karakteristici dolazi u pitanje, budući da su likovi s punim vokalom na mjestu poluglasa u slabome položaju (poput * meša, ${ }^{*}$ Vuzam i sl.) široko rasprostranjeni i diljem kajkavskoga teritorija. 
(Mužek 2020:213, bilj. 40). No, ona nije jedini primjer te inovacije: uz nju su u građi ovjereni i primjeri snáxa, láfku, làže 'lakše', stáklo i pás, pri čemu je moguće i da je utjecaj na tu promjenu došao iz standardnoga jezika, i da izdvojeni primjeri svjedoče početku endogena procesa zamjene poluglasa vokalom $a$ i u kratkom naglašenom slogu. U dvama je primjerima (màkar, sàmo) na mjestu etimološkoga $a$ potvrđen pseudopoluglas, no zbog maloga broja potvrda u govoru Vrbanaca riječ je ipak o jednosmjernoj opoziciji $ə>a$. U rijetkim potvrdama vidljivi su i relikti poluglasa u nenaglašenoj poziciji: partižak, partî̌ka 'hodnik'. Ovakvim razvojem poluglasa narušena je kajkavska formula jednačenja odrazâ poluglasa i jata, što je i očekivano na jugozapadnome dijelu cjelokupnoga kajkavskoga teritorija.

Odrazi stražnjega nazala i samoglasnoga l jednače se u većini kategorija (u korijenskome morfemu, te u gramatičkim morfemima u A jd. imenica $e$-deklinacije i u 3 . mn. prezenta), a rezultat su jednačenja vokali $u / \bar{u}$ : rúbača, subòta, gûskẹ $\mathrm{N}$ mn., mûš, žẹlûdac, vrućĩna, kutĩćak, sûsẹdi D jd., plấu A jd., na pâšsu A jd., slũgu A jd., žĩvęju, mučĩju, vẹlîju 3. mn. prez.; tûkli, žûtẹ A mn., dûga pr. ž., jábukẹ. U glagolima druge vrste na mjestu ishodišnoga morfa *-no- dolazi morf -na-: napuxnále, poginal, púknal, klẹknàti, nakrệnal, prigriznali, istrignal. Riječ je o izoglosi koja, uz još nekoliko oaza na sjeveru Istre, na području Kalnika i na sjeveru Hrvatskoga zagorja (usp. kartu u Celinić-Menac-Mihalić 2017:100) izdvaja cjelokupno područje plješivičkoozaljskoga dijalekta iz cjeline hrvatskoga jezika s prevladavajućim morfom -ni- (i drugim fonološkim inačicama, $<{ }^{*}-n y-$ ).

Polazni ${ }^{*} u /{ }^{*} \bar{u}$ razvili su se $u$ današnje vokale $u / \bar{u}$ : potpisûję 3 . jd. prez., zakũril pr. r. m., cúlo 'marama s travom koja se nosi na glavi', kúća, kurî́ak, sušîla pr. r. ž. Vokal $\bar{u}$ nastaje $\mathrm{u}$ analiziranu govoru i kontrakcijom sloga: $z$ mû tệtu I jd. Protetsko $v$ potvrđeno je u primjerima u kojima se $\mathrm{u}$ inicijalnome položaju primarno nalazio vokal $u$ podrijetlom od etimološkoga * $u$ i stražnjega nazala, dok se u riječima u kojima je $u$ toj poziciji došlo do zamjene $o \rightarrow u$ protetsko $v$ ne pojavljuje (usp. gore): vûgarak, vưra, vû tẹ, vúčitẹl, vûsko.

Polazni *a/*ā razvili su se u današnje vokale a/ăg: trã̃va, brãnę $\mathrm{N}$ mn., žâga, săka, sẹ,âaki, šlâfẹ A mn., pâažul, nâjjstàrija, rácẹ $\mathrm{N}$ mn., làjti $\mathrm{N}$ mn., pojáta, imal pr. r. m.

Polazni ${ }^{*} i /{ }^{*} \bar{\imath}$ u razvoju također nisu pokazali značajnijih odstupanja: dobĩla pr. r. ž., svî́n G mn., trî, kî̌nni, briši 2. jd. imp., nệki. 


\subsection{Konsonanti}

\subsubsection{Inventar i realizacija}

Inventar konsonanata u mjesnome govoru Vrbanaca čini 8 sonanata te 18 opstruenata:

\begin{tabular}{|c|c|c|c|c|c|}
\hline \multicolumn{3}{|c|}{ sonanti } & & \multicolumn{2}{|c|}{ opstruenti } \\
\hline & & $m$ & $p$ & $b$ & $f$ \\
\hline l & $r$ & $n$ & $t$ & $d$ & \\
\hline$j$ & & $\dot{n}$ & $c$ & & s \\
\hline & & & $c^{\prime}$ & 3 & ś \\
\hline & & & $\check{c}$ & & $\check{s}$ \\
\hline & & & $k$ & $g$ & \\
\hline
\end{tabular}

U konsonantskome inventaru mjesnoga govora Vrbanaca čuva se razlika između bezvučnih palatalnih afrikata č i ć: čúda 'mnogo', začinîla pr. r. ž., Kupčina, vrüćak 'vrućina', césram D mn., ćû 1. jd. prez., plaćáli pr. r. m. Dihotomija 3 : je zastupljena afrikata ś čiji je izgovor blizak štokavskome ś.

Sonanti $l$ i $n$ ispred prednjih se vokala ostvaruju palataliziranim alofonima [l'] $i$ [n']: [bòl'esna, lệt $\mathrm{G}$ mn., tâncali, tul'iko, plaćáli, mliñar, zakláli,

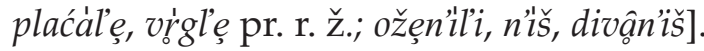

\subsubsection{Distribucija konsonanata}

Svaki konsonant može stajati u inicijalnom i medijalnom položaju, dok u finalnome položaju postoji ograničenje, odnosno zvučni opstruenti ne dolaze $\mathrm{u}$ finalnome položaju te $\mathrm{u}$ prijedlozima ispred bezvučnih opstruenata. U tim se pozicijama mijenjaju svojim bezvučnim parnjacima: brệk, rột, Zãgrẹp, pûš, vộs, rộk. Na kraju riječi te u poziciji ispred bezvučnih su-

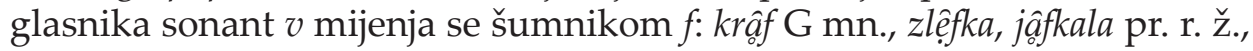
Kậrlofcu L jd., nófcę A mn.

Opstruent $x$ stabilnom je jedinicom konsonantskoga inventara, u svima trima položajima: xiža, xlẹbof, xłrga, kẹxlâak 'ukras na peći', plâxtẹ N mn., skúxali pr. r. m., rùxo, snáxa. Međutim, u dijelu primjera u inicijalnoj i finalnoj poziciji on izostaje: nî tệla, fiži L jd., ranili pr. r. m., ladętina, strâa; u dočetnome položaju gramatičkih morfema genitiva množine stàrijif, tệf supstituiran je fonemom $f$. Nakon zamjene $-v>-f u$ finalnome položaju fonem $f$ zabilježen je i u riječi krüf. Budući da je u govoru Domagovića fonem $x$ nestao iz sustava (Zečević 1981:305), a u govoru Tuškana javlja se samo u funkciji sprječavanja hijata (Mužek 2020:224), logičnim se nameće pitanje 
njegove ovjere $u$ govoru Vrbanaca smještenome između dvaju navedenih punktova. Uzimajući u obzir učestalo prebacivanje koda kod informanata, ali i potvrde u kojima $x$ izostaje ili se supstituira, polazimo od pretpostavke da je fonem $x$ u ovome govoru pojava novijega datuma čije je unošenje potaknuto izvanjezičnim razlozima.

U prezentskoj i imperativnoj osnovi glagola prefigiranih od glagola 'ići' čuva se skup jd, a u infinitivnoj skup jt: prệjdi 2. jd. imp., dộjdẹ 3. jd. prez., zâjjti, dọjti.

Finalno je -l na dočetku pr. r. m. r. jd. neizmijenjeno, kao i na dočetku imenica i pridjeva: kášļal, otpệlal, zákasnil, ródil, rãanil, pósal, okrûgal.

\subsubsection{Povijesni razvoj}

Najveći dio konsonanata (/vjl l rmnńpbtdcsž̌š žkg/) kontinuira konsonante ishodišnoga sustava, stoga ćemo se ovdje detaljnije osvrnuti samo na posebnosti.

Općeslavenskom jotacijom prvotnoga ${ }^{*} \hat{(}\left(<\right.$ psl. $\left.{ }^{*} t\right)$ u govoru se Vrbanaca razvio fonem ć: svệ́a, vrẹća, plẹća, vrûć, pệć. Sekundarni skup *taj dao je također ć: bráća, prolẹcéẹ. Fonem ć u potvrdi ćẹdan nastao je i stapanjem $t \mathrm{i}$ $j$ nakon ispadanja poluglasa. Praslavensko ${ }^{*} d j$, odnosno opsl. * ${ }^{*}$ dalo je $j$ : mẹja, mláji, narệjẹn, posâjện, slájẹ. Sekundarni skup *daj dao je ś: sûśe, rožâak.

Na mjestu suglasničkoga skupa st́ $\left({ }^{*} s t j={ }^{*} s k j\right)$ dolazi fonem ś: ogńiśs, rûškẹ strniśicę, lęžalissé, spuśálo pr. r. s., dvuriśe, strniśe, pûśam 1. jd. prez., gưsé 'pril. komp., gušće', tr̂ssée, piśanac II pišẹ. Sekundarni skup stj (<*staj) također je jotacijom dao ś: liśé, z maśû I jd. U sekundarnome je skupu zdj $\left(<{ }^{*} z d j j\right)$ nakon ispadanja dentala $d$ i poluglasa jotacijom $z$ i $j$ dobiven fonem ź potvrđen u riječi grộźe. Fonem ź ima marginalan status: osim navedene potvrde, zabilježen je u građi još samo u primjeru riźiné, vjerojatno kao rezultat analogije. Jotacija nije provedena u primjerima kitję, šibjẹ, grộjjẹ.

Prijedlog *sa dao je kontinuante $z / s$ čija raspodjela ovisi o (be)zvučnosti narednoga konsonanta: z bàtinami, z nầmi, z mẹtlâmi, z mầmu, s kubilami, s kộli. Razvoj * ${ }^{*}$ - > vu-zabilježen je u riječima Vúzam (i izvedenici vuzmệnka) i vîš, a ${ }^{*} v \partial(-)>v / f$ u potvrdama vnùk, vnùka, v Zâgrẹbu, $f$ Kanãdi, f kûpcu. U oblicima glagola 'uzeti' odraz polaznoga prefiksa *vo- je ø: zệli pr. r. m., zàmęm 1. jd. prez.

Staro palatalno *ŕ otvrdnulo je, a slijed $r+j$ potvrđen je sporadično: $\mathrm{u}$ primjeru búrja te u prezentskoj paradigmi nekih glagola: prigovârja 3. jd. prez., orję 3. jd. prez. Kajkavska je depalatalizacija u građi potvrđena samo u primjerima na zẹmli, fâjnkẹ̦ ${ }^{22} \mathrm{~A}$ mn.

22 Leksem fanjak u značenju 'buhtla' potvrđen je na širem karlovačkom području. 


\subsection{Prozodija}

\subsubsection{Inventar i realizacija}

Naglasni sustav mjesnoga govora Vrbanaca čine tri akcenta: kratki $(\dot{a})$,

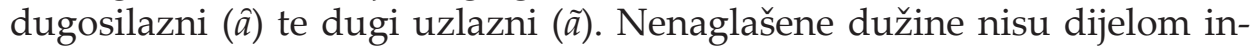
ventara pa je opreka po kvantiteti potvrđena samo u naglašenome slogu, a u dugom naglašenom slogu potvrđena je i opreka po tonalitetu.

Kratki je naglasak fonetski često trom i u izgovoru vrlo dug. Međutim, ne može se govoriti o fonološkome duljenju kratkoga naglaska, budući da minimalni parovi između kratkih i naknadno produljenih vokala nisu potvrđeni (npr. kubila [kubĩla] u primarno ili sẹsstra [sẹsstra] u sekundarno naglašenome slogu).

\subsubsection{Distribucija i razvoj}

Naglašeni mogu biti svi vokali te slogotvorno $r$. Akcent se pomaknuo s polazno naglašene ultime, otvorene i zatvorene, na polazno kratku (rẹebro, jẹzik, sẹllo) i polazno dugu penultimu (pĩsmo, glãva, kũpac), što znači da je u govoru Vrbanaca dezoksitoneza potpuno provedena, i to najkasnije u prvoj polovici prošloga stoljeća budući da se likova s kratko naglašenom ultimom ne sjeća ni starija ispitanica rođena 1935. Oksitoneza je u karlovačkome arealu potvrđena 70-ih godina prošloga stoljeća tek u nekoliko sela na istočnoj karlovačkoj periferiji (Finka-Šojat 1973:103).

Raspodjela kratkoga naglaska podrijetlom od starog kratkog u mjesnome govoru Vrbanaca slijedi uobičajeni obrazac distribucije naglasaka $\mathrm{u}$ konzervativnijih govora u kojima se kratki naglasak zadržava na starome mjestu u medijalnome slogu. Svojstven je i inicijalnoj poziciji i jedinomu slogu, dok se u finalnome slogu javlja samo u posuđenica: niš, sẹ 'sve', sikkaj, tẹlci, jẹ̀nu A jd., škủla, pojàtes $\mathrm{N}$ mn., kulẹno, blazina, licitẹri, kupiti, kupováli, praktikànt, mužikànt. Osim toga, kratki se naglasak u dijelu primjera u govoru Vrbanaca javlja i na mjestu neocirkumfleksa, pri čemu se izdvajaju kategorije lokativa jednine muškoga roda (poput po plòtu L jd., ali usp. dolje na plậu).

Dugi silazni naglasak dolazi u svima trima pozicijama te $\mathrm{u}$ jedinome slogu: dvâ, jâ̆, tâčcki L jd., mlâdi, vệcée žiškẹ, klâsjẹ, divâaniš 2. jd. prez., krumpîr, vodẹ $\mathrm{G} \mathrm{jd}$., v jẹsẹnî L jd. Raznovrsnoga je podrijetla. Javlja se na mjestu staroga cirkumfleksa (snệk 'snijeg', sệni 'sijeno'), na mjestu staroga akuta te na mjestu novoga akuta $\mathrm{u}$ jedinome i finalnome slogu dosljedno (žện $\mathrm{G}$ mn., držîm, bolî, kusî 3. jd. prez.), a u ostalim pozicijama fakultativno. Na mjestu staroga akuta razvio se neocirkumfleks u nizu kajkavskih kategorija (usp. Ivšić 1936:71): na plậcu L jd., bâabu I jd., košăra, košâarami I mn., korîta 
$\mathrm{N}$ mn., čûjem, vîdim, kupûjem, izvâadim, narệžem, mệla, pâažul, mlînar, govệdina, svâadbo A jd.

Dugi uzlazni naglasak starijega je i novijeg postanja. Na mjestu kajkavskoga neoakuta još uvijek je prisutan, no uglavnom s brojnim kolebanjima i dubletama, a nerijetko su potvrđeni primjeri samo s dugosilaznim naglaskom: širộki, jãjjca Il jâjjca, rệbra, kộzji, dẹbệli, na kộli L mn. Premda su dublete potvrđene i kod uzlaznoga naglaska retrakcijskoga postanja, u toj je poziciji stabilniji: mlệko I| mlệko, glẫva, kũvaš, vĩni || vĩne || vĩno.

Zaključno, naglasni je sustav Vrbanaca još uvijek tronaglasni premda je jasno prisutna tendencija zamjene akuta dugosilaznim naglaskom, kako na starim pozicijima (sǔša), tako i u novim $(r \hat{u} k a)$ pa treba pretpostaviti da će dublete poput jãjjca II jầjca u dogledno vrijeme nestati, u korist inačica s dugosilaznim naglaskom.

\section{Mjesni govor Vrbanaca u kontekstu prigorske kajkavštine}

Usporedimo li mjesni govor Vrbanaca iz kuta fonologije s njemu najbližim obrađenim govorima, mjesnim govorima Tuškanâ i Domagovića (opcionalno i s udaljenijim govorom Ozlja), uočit ćemo da među njima postoje brojna podudaranja. Broj njihovih međusobnih razlika na fonološkoj razini nešto je manji, a u ovome poglavlju pokušat ćemo interpretirati i jedne i druge značajke, imajući u vidu više hijerarhijske sustave i uklopljenost govora Vrbanaca u njih.

Prema broju i dosljednosti provedbe vokalskih zamjena na promatranome prostoru prednjači mjesni govor Domagovića u kojem je novijim istraživanjima evidentirano pet tipova funkcionalnih zamjena. Mjesni govor Tuškanâ u tome je pogledu jednostavniji i umnogome se poklapa s govorom Vrbanaca: zajedničke su im neutralizacije $e \rightarrow i$ te $o \rightarrow u$ u nenaglašenu slogu, dok jednačenje vokala $o$ s odrazom jata i u naglašenu slogu (tip stẹll), svojstveno govoru Vrbanaca, u Tuškanima nije potvrđeno. Osim toga, u svima trima govorima zamjena jata odskače od ikavsko-ekavske situacije u govorima ozaljskoga tipa. Zamjena $o \rightarrow e \rightarrow i$ u govoru Vrbanaca provodi se gotovo dosljedno, što nije slučaj sa zamjenom $o \rightarrow u$. Naime, prema primjerima donesenima u poglavlju 3.1.2., u nenaglašenu slogu vokal $o$ zamjenjuje se vokalom $u$ iza gravisnih konsonanata, alveolara $l$ te $\mathrm{u}$ inicijalnome položaju, a iza ostalih konsonanata vokalom e, odnosno $i$. Iz brojnih primjera $u$ radu vidljiva su odstupanja od navedene raspodjele, a nestabilnost zamjene $o \rightarrow u$ naspram veće konzekventnosti zamjene $o \rightarrow e$ bjelodano se ogleda u primjeru potrišiti. Međutim, kako je promjena $o \rightarrow u$ u govoru Tuškanâ posve nestalna, a u Domagoviću pak stabilna, govor se 
Vrbanaca svojim kolebanjima na planu fonoloških neutralizacija (kubîl G $\mathrm{mn}$. prema korita $\mathrm{N} \mathrm{mn}$.) među njima sasvim uklapa kao prijelazni tip govora, što se tiče vokalskih zamjena.

No, obilježja prijelaznosti analiziranoga govora lijepo se ogledaju i u akcentuaciji. Ozaljski tip govorâ, pa tako i govor Tuškanâ, na akcenatskome planu određuje duljenje primarno kratkoga vokala u sekundarno naglašenoj poziciji. U govoru Vrbanaca ta pojava nije registrirana, kao ni $u$ drugim govorima draganićkoga tipa (Mužek za draganićko selo Lug donosi potvrde vöda i žệna) te u pravcu istoka u Domagoviću također (GalićLisac 2017:138). Posebno je u analiziranom mjesnom govoru uočljivo kolebanje neoakuta na starome mjestu. Uz moguću opću tendenciju akcenatske konvergencije s obližnjim govorom Karlovca čija je osnovna akcenatska slika obilježena generalnom metatonijom $\tilde{a}>\hat{a}$ (Finka-Šojat 1973:9798), razloge akcenatskih dubleta sũša II sûša valja potražiti ponajprije u geografskome položaju govora Vrbanaca, na samoj granici zapadnijih prigorskih govorâ u kojima je neoakut na primarnome mjestu posve izgubljen i istočnijih u kojima se on dobro čuva.

Sukladno navedenomu, i prema vokalskome kriteriju i prema akcenatskome, mjesni bi se govor Vrbanaca odredio kao prijelazni tip govora između ozaljskoga i prodindolskoga tipa prigorske kajkavštine.

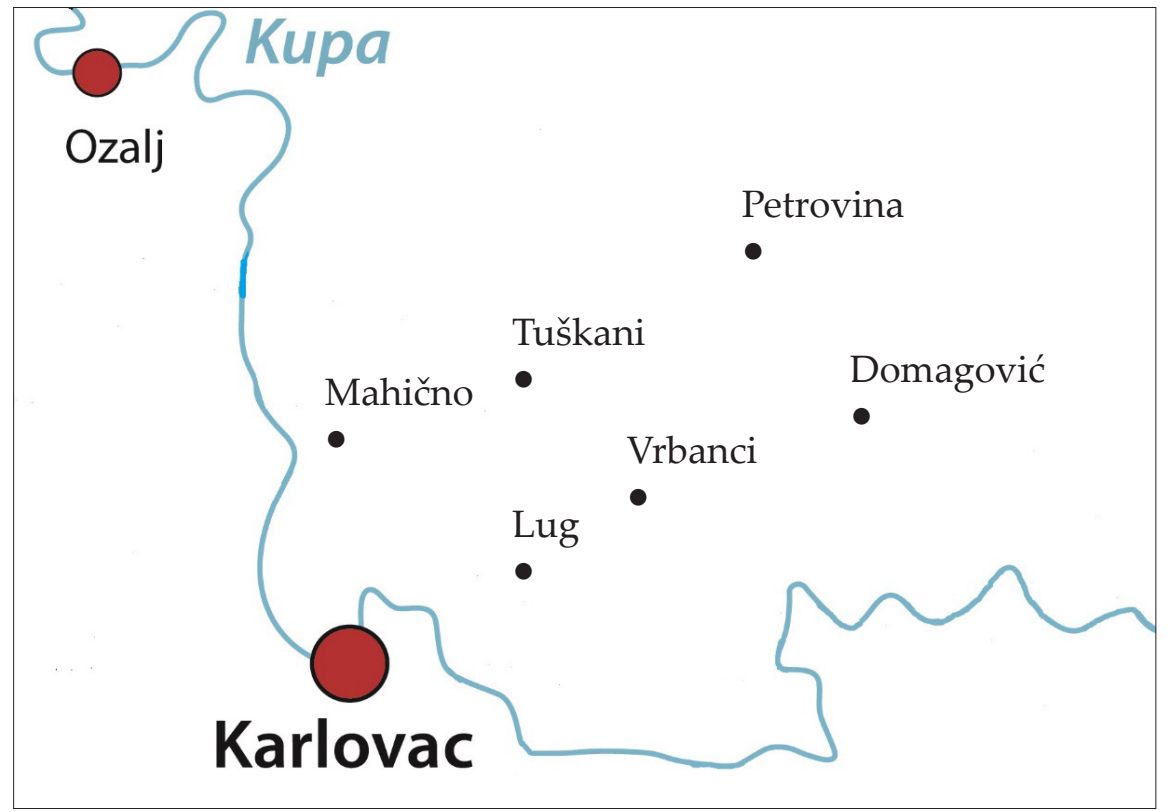

Slika 1. Položaj govorâ na jugozapadnome polu plješivičko-ozaljskoga dijalekta 


\section{Zaključak}

Mjesni govor Vrbanaca u draganićkoj skupini govora brojnim obilježjima potvrđuje pripadnost plješivičko-ozaljskomu kajkavskomu dijalektu. Navest ćemo zaključno samo neke: neutralizacije fonoloških opreka, prisutnost fonema ś i ź, te č i ć u konsonantskome inventaru, bazično kajkavska akcentuacija i dr. U uvodnome poglavlju istaknuli smo položaj draganićkoga područja na dijalektološkim zemljovidima kao graničnoga prema čakavskome narječju. Budući da su opozicije ś i ź te č i ć (u dijalektološkoj literaturi često smatrane čakavskima) imanentne cijelomu dijalektu, o omjeru kajkavskih i čakavskih značajki valjalo bi raspravljati na toj hijerarhijskoj razini. Kako se te izoglose protežu ipak dosta sjevernije od čakavsko-kajkavskih govora južnije karlovačke okolice u kojima čakavizmi dominiraju, nema sumnje da je cjelina dijalekta u suštini kajkavska, a spomenute konsonantske opreke mogu se tumačiti arealno.

Zanimljiva je i prijelazna pozicija govora Vrbanaca u odnosu na susjedne govore prigorskoga tipa, posebice u svjetlu akcenatskih izoglosa, poput neutralizacije dugoga uzlaznoga i dugoga silaznoga naglaska. Istočniji govori draganićke skupine, u smjeru Domagovića, zasigurno bolje čuvaju neoakut. Uzmemo li u obzir činjenicu da je potez Tuškani - Vrbanci - Domagović dugačak tek 15-ak km, jasno je da je riječ o geografski malome, ali dijalektološki (posebice u kajkavološko-klasifikacijskome kontekstu) izuzetno važnome području. 
Marina Marinković: Fonološke značajke mjesnoga govora Vrbanaca: prilog proučavanju... FILOLOGIJA 75(2020), 99-118

\section{Literatura}

Barac-Grum, Vida; Vesna Zečević. 1991. Prilog proučavanju vokalskih zamjena u čakavskom i kajkavskom narječju. Cakavska rič, 19/2, 63-69.

Brozović, Dalibor. 1970. Standardni jezik. Zagreb: Matica hrvatska.

Brozović, Dalibor. 1988. Kajkavsko narječje. Jezik, srpskohrvatski/hrvatskosrpski, hrvatski ili srpski. Zagreb: Jugoslavenski leksikografski zavod »Miroslav Krleža«, 90-98.

Celinić, Anita; Mira Menac-Mihalić. 2017. Poveznice i razdjelnice u srodnim jezičnim sustavima. Jezikoslovni zapiski, 23, 1, 93-105.

Finka, Božidar; Antun Šojat. 1973. Karlovački govor. Hrvatski dijalektološki zbornik, 3, 77-152.

Galić, Josip; Josip Lisac. 2017. Kajkavski govori u okolici Jastrebarskoga: Petrovina i Domagović. Hrvatski dijalektološki zbornik, 21, 129-145.

Grčević, Martina. 2008. Imena hrvatskih naselja. Rijeka: Maveda - Hrvatsko filološko društvo.

Hrvatski mjesni rječnik. 2016. Ur. Nataša Bašić-Kosić. Zagreb: Leksikografski zavod »Miroslav Krleža«.

Ivić, Pavle. 1968. Procesi rasterećenja vokalskog sistema u kajkavskim govorima. Zbornik za filologiju i lingvistiku, 11, 57-69.

Ivšić, Stjepan. 1936. Jezik Hrvata kajkavaca. Ljetopis JAZU, 48, Zagreb, 4788.

Kapović, Mate. 2011. Accentuation of $i$-Verbs in Croatian Dialects. Accent Matters: Papers on Baltic and Slavic Accentology. Ur. Tijmen Pronk i Rick Derksen. Amsterdam - New York: Rodopi, 109-233.

Kapović, Mate. 2015. Povijest hrvatske akcentuacije. Fonetika. Zagreb: Matica hrvatska.

Laszowski, Emilij. 1899. Stara hrvatska županija Podgorska. Zagreb: Tisak dioničke tiskare.

Lončarić, Mijo. 1977. O sustavima u dijalektologiji. Rasprave Instituta za je$z i k, 3 / 1,43-58$.

Lončarić, Mijo. 1996. Kajkavsko narječje. Zagreb: Školska knjiga.

Lopašić, Radoslav. 1883. Obćina draganićka. Zagreb: Tiskara Narodnih novinah.

Maresić, Jela. 2017. Prefiksi pre-, pro-, pri- i pra- u kajkavskome narječju. Hrvatski dijalektološki zbornik, 21, 217-228.

Maresić, Jela; Vladimir Miholek. 2011. Opis i rječnik đurđevečkoga govora. Đurđevac: Gradska knjižnica Đurđevac.

Marinković, Marina. 2017. Iz fonologije mjesnoga govora Zadobarja: čakavsko-kajkavske interferencije na zapadnome karlovačkome području. Jezikoslovni zapiski, 23, 1, 107-123. 
Marina Marinković: Fonološke značajke mjesnoga govora Vrbanaca: prilog proučavanju...

FILOLOGIJA 75(2020), 99-118

Mitrinović, Vera. 1990. Poljski glagolski prefiks prze- i njihovi srpskohrvatski ekvivalenti pre- i pro-. Beograd: Naučna knjiga.

Moguš, Milan. 1977. Čakavsko narječje. Zagreb: Školska knjiga.

Mužek, Matija. 2020. Fonološki opis govora Tuškanâ. Rasprave: Časopis Instituta za hrvatski jezik i jezikoslovlje, 46/1, 191-254.

Rožić, Vatroslav. 1893-1894. Kajkavački dijalekat u Prigorju. Rad JAZU 115, 116, 118, Zagreb, (I): 68-136; (II): 113-174; (III): 55-115.

Strohal, Rudolf. 1901. Jezične osobine u kotaru karlovačkom. Rad JAZU, 146, 78-153.

Šebetić, Krunoslav. 2015. Alijeteti i alteriteti draganićkog govora. Završni rad. Rijeka: Filozofski fakultet.

Šimunović, Petar. 2009. Uvod u hrvatsko imenoslovlje. Zagreb: Golden marketing - Tehnička knjiga.

Težak, Stjepko. 1981. Ozaljski govor. Hrvatski dijalektološki zbornik, 5, 203 428 (s kartama).

Turk, Marija. 1996. Inherentna distinktivna obilježja i distribucija fonema u hrvatskome jeziku. Govor, XIII, 1-2, 41-54.

Vermeer, Willem. 1982. The Rise and Fall of the Kajkavian Vowel System. Studies in Slavic and General Linguistics, 3, 439-477.

Zečević, Vesna. 1981. Domagović (OLA 27). Fonološki opisi srpskohrvatskih/ hrvatskosrpskih, slovenačkih i makedonskih govora obuhvaćenih opšteslovenskim lingvističkim atlasom. Ur. Pavle Ivić. Sarajevo: Akademija nauka i umjetnosti Bosne i Hercegovine, 301-305.

Zečević, Vesna. 1993. Fonološke neutralizacije u kajkavskom vokalizmu. Zagreb: Zavod za hrvatski jezik Hrvatskoga filološkog instituta.

\title{
Phonological features of Vrbanci village local dialect: a contri- bution to the study of Draganić Kajkavian dialect
}

\begin{abstract}
The paper describes the phonological level of Vrbanci village local dialect on the basis of material collected through author's own field research. The village of Vrbanci is part of the Municipality of Draganić located near the town of Karlovac. In previous dialect research, Draganić dialects have not been described in more detail, although they are at the very crossroads of two Kajkavian dialects: plješivičko-ozaljski and vukomeričko-pokupski dialect (and two of Ivšićs groups, the first and the third). The analysis of dialectological material showed that the phonology of this dialect differs somewhat from the neighboring dialects of the Ozalj type, but also that there are a number
\end{abstract}


of phonological features that they share: monophthonic vocalism, fricatives $\dot{s}$ and $\dot{z}$, afrikates $\check{c}$ and $c$, preserving the semivowel in a syllable with a short accent etc. On the other hand, jat in both long and short syllables gives a closed ê/e (unlike with the nearby western dialects with the Ikavian-Ekavian replacement of jat), and the distribution of neoacute is the same as in prodindoltype speeches, with neoacute occurring in both old and new places. Phoneme substitutions $(o \rightarrow u, o \rightarrow e, e \rightarrow i ; o \rightarrow a$ rarely) are especially noticeable in this speech, which largely identifies it with other speeches on the easternmost branch of the Plješivica-Prigorje Kajkavian dialect.

Considering the stated common features, this paper positions Vrbanci local dialect more precisely on the map of the southwestern part of the Kajkavian dialect, on the Ozalj - Tuškani - Domagović line.

Ključne riječi: plješivičko-ozaljski kajkavski dijalekt, fonologija, fonološke neutralizacije, Draganić, Vrbanci

Keywords: plješivičko-ozaljski Kajkavian dialect, phonology, phonological neutralizations, Draganić, Vrbanci 